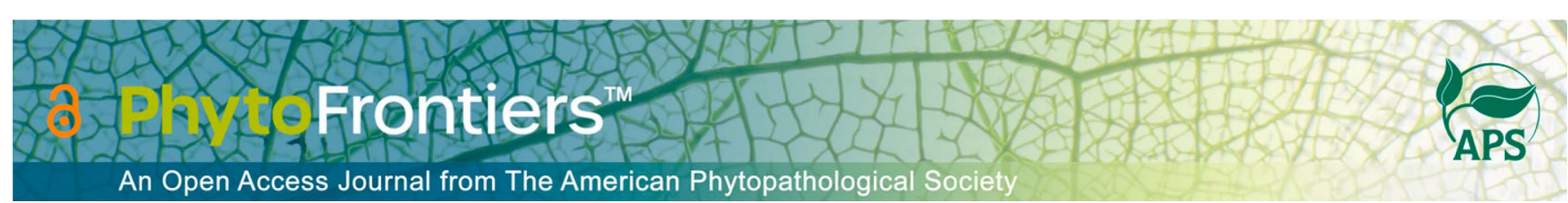

\title{
Research
}

\section{Validation of Quantitative and Digital Polymerase Chain Reaction Assays Targeting the Mating Types of Phyllosticta citricarpa, the Causal Agent of Citrus Black Spot}

\author{
Hector Urbina ${ }^{1,+}$ (D) | Taylor Smith ${ }^{1} \mid$ Callie Jones $^{1} \mid$ Xiaoan Sun $^{1,2} \mid$ John McVay $^{1}$ (D) | \\ Caroline Walker $^{1}$ | Leroy Whilby ${ }^{1}$ | Greg Hodges ${ }^{1}$ | Trevor Smith $^{1}$ |
}

\footnotetext{
1 Division of Plant Industry, Florida Department of Agriculture and Consumer Services, $1911 \mathrm{SW}$ 34th St., Gainesville, FL 32608, U.S.A.

2 Weifang University of Science and Technology, 1299 Jinguang Street, Shouguang, Shandong Province, 262700, China
}

+ Corresponding author: H. Urbina; hurbinay@
gmail.com Accepted for publication 20 April 2021

\section{Funding}

United State Department of Agriculture-Animal and Plant Health Inspection Service Citrus Health Response Program Grant Number AP19PPQFO000C049.

$e$-Xtra: Supplementary materials are available online.

The author(s) declare no conflict of interest.

\begin{abstract}
Citrus black spot (CBS) is a disease caused by the ascomycetous fungus Phyllosticta (formerly Guignardia) citricarpa (Botryosphaeriales, Pezizomycotina) currently present in citrus groves in five counties in southwest Florida. Within Florida, $P$. citricarpa shows limited reproduction via asexual sporulation due to the presence of only one (MAT1-2-1) of the two required mating types for sexual reproduction. Here, we present two novel PCR assays standardized in quantitative PCR (qPCR) and digital PCR (dPCR) platforms to distinguish both mating types (MAT1-1-1 and MAT1-2-1) of $P$. citricarpa to monitor for the potential introduction of the MAT1-1-1 mating type into Florida and a novel protocol for DNA extraction from asymptomatic leaves. During citrus harvesting season $2018-19$, fruit lesions as well as asymptomatic leaves adjacent to symptomatic fruit and asymptomatic trees in CBS-infected groves were surveyed for $P$. citricarpa presence and mating types. Results support the presence of only the MAT1-2-1 mating type in Florida, after surveying more than 1,145 citrus fruit lesions. We also confirmed the limited dispersal ability of the asexual state of $P$. citricarpa in Florida in 10 groves using the enhanced capabilities of the $\mathrm{dPCR}$ platform in the detection of $P$. citricarpa directly from asymptomatic leaves with low pathogen inoculum.
\end{abstract}

Keywords: Ascomycota, asexual state, CBS, Dothideomycetes, dPCR, Florida, Guignardia, Phyllostictaceae, qPCR, sweet orange

Citrus black spot (CBS) is a plant disease caused by the ascomycetous fungus Phyllosticta (= Guignardia) citricarpa (McAlpine) Aa (Phyllostictaceae, Botryosphaeriales, Pezizomycotina). It is known to affect all citrus species and varieties in commercial groves in tropical and subtropical countries with warm and wet summers, including Australia, Brazil, China (mainland and Hong Kong), India, 
Indonesia, Japan, Kenya, Mozambique, Nigeria, Peru, Philippines, Swaziland, Taiwan, Uruguay, Uganda, United States (Florida), Venezuela, and Zimbabwe (Schubert et al. 2010; USDA APHIS 2020). More recently, CBS was reported in Tunisia (Boughalleb-M'Hamdi et al. 2020), confirming predictions that $P$. citricarpa is able to establish in such dry ecosystems as Mediterranean-type weather (Martínez-Minaya et al. 2015), putting at risk the citrus industry in Europe.

The disease cycle of CBS was described in detail by Tran et al. (2017), in which authors pointed out that $P$. citricarpa is a heterothallic species capable of reproducing both sexually (ascospores from ascoma) and asexually (conidia from pycnidia). Compatible sexual strains containing a single idiomorph of MAT1 (containing the MAT1-1-1 gene) and MAT2 (containing the MAT1-2-1 gene) are required for ascoma formation. In early summer, aerial ascospores are released from fruiting bodies. In early winter, conidia containing a single MAT locus germinate from pycnidia, which are generally located on the surface of fruit and leaves (latent phase) (Supplementary Fig. S1). Infected fruit and leaves drop prematurely to the ground in late winter. Following spore germination, if compatible mycelia come into contact, they will undergo sexual reproduction (Tran et al. 2017, 2020; Wang et al. 2016). Additionally, P. citricarpa produces spermatia (Supplementary Fig. S1), structures that act as gametes but do not contribute directly to dispersal and infection (Higgins 1929; Tran et al. 2017; Wikee et al. 2011).

The majority of countries where CBS is present have both mating types, and $P$. citricarpa disperses using both asexual and sexual spores (Dewdney et al. 2016; Wang et al. 2016). In Florida, however, P. citricarpa dispersal is accomplished primarily asexually, by water splash (Perryman et al. 2014); this was first demonstrated by Wang et al. (2016), in which a molecular analysis of 113 P. citricarpa isolates revealed only a single mating type (MAT2), and no genetic variability among strains. Carstens et al. (2017) later confirmed these results by applying whole-genome sequencing and simple sequence repeat approaches on $P$. citricarpa strains recovered from five continents. This study also points out that the spread of $P$. citricarpa worldwide is mainly mediated by humans during exchange of plant materials and produce, and the genetic makeup of $P$. citricarpa populations in Florida is similar to those in South Africa and Australia.

By the time CBS was discovered in Florida (Schubert et al. 2010), the disease was already measurably impacting the state's citrus industry. The six Florida counties (Charlotte, Collier, Glades, Hendry, Lee, and Polk) (USDA APHIS 2020) currently affected by CBS have experienced increased growing costs along with diminishing production (Fig. 1). These economic stressors are compounded by increased restrictions on international exportation, affecting nearly $40 \%$ of the total international citrus exports from the state (Hudson 2019). In the longstanding presence of citrus greening, caused by 'Candidatus Liberibacter asiaticus' (Halbert and Manjunath 2004; McVay et al. 2019), and citrus canker, caused by Xanthomonas citri pv. citri (Gottwald et al. 2001), CBS is further stressing the already decimated Florida citrus industry.

Beginning with the discovery of CBS in southwest Florida, quarantine measures have continuously been set in place to reduce and slow the spread of the disease throughout groves in the area. In order to make informed regulatory decisions, it is necessary to confirm the presence of only one mating type, MAT2, because it pertains directly to the dispersal capability of the organism, as well as to establish protocols for early detection from asymptomatic leaves and fruit using sensitive molecular assays. Here, we design, evaluate, and standardize quantitative PCR (qPCR) and digital PCR (dPCR) protocols for the detection of both mating types of $P$. citricarpa and migrate a previously published qPCR assay targeting the internal transcribed spacer (ITS1) (Bonants et al. 2003; Van Gent-Pelzer et al. 2007) to a dPCR platform for more sensitive detection of this fungal pathogen from symptomatic fruit and asymptomatic green canopy leaves. This work will facilitate the monitoring of mating types of $P$. citricarpa and investigations into its distribution and dispersal capabilities among citrus groves in affected areas.

\section{MATERIALS AND METHODS}

\section{Sampling of CBS symptomatic fruit and asymptomatic canopy leaves}

Symptomatic citrus fruit (up to six pieces of fruit) and asymptomatic green canopy leaves (up to 15 leaves) (hereafter "leaves") were sampled during one citrus harvesting season (2018-19) in groves and residential areas under quarantine (previously known), extension of quarantine (newly discovered), and potential (Supplementary Table S1; Fig. 1A). Inspectors of the Florida Department of Agriculture and Consumer Services, Division of Plant Industry (FDACS-DPI) and the United States Department of Agriculture (USDA) collected symptomatic fruit as well as leaves adjacent to trees containing symptomatic fruit. Samples from the groves were sent to FDACS-DPI Section of Plant Pathology (Gainesville, FL, U.S.A.) for diagnosis using both microscopic and molecular analyses. Positive samples from groves that would extend the quarantine area were sent to the National Identification Services, USDA (Beltsville, MD, U.S.A.), for confirmation of diagnosis (Supplementary Table S1).

\section{Tree quad sampling in CBS asymptomatic groves}

An orthogonal nonparametric sampling scheme was designed to investigate the ability to detect $P$. citricarpa from asymptomatic citrus trees adjacent to CBS-positive trees and to gather information on how the pathogen disperses within groves of Citrus $\times$ sinensis (L.) Osbeck 'Valencia' (sweet orange). Samples were collected from nine groves: seven which had no symptomatic fruit but were CBS-positive the previous harvesting season (2017-18) and two in which symptomatic fruit were found in the 2018-19 citrus harvesting season ("positive groves", 8G1 and 9G1) (Supplementary Table $\mathrm{S} 2$ ). The positive groves were also sampled during June (8G2 and 9G2) (Supplementary Table S2), after citrus harvesting, when pathogen inoculum is present at putatively low levels. FDACS-DPI inspectors pulled leaves from citrus trees within the row and in adjacent rows from the original CBS-positive tree (disease symptoms may not have been present in the tree by the time of this study because $P$. citricarpa was detected during previous citrus harvesting season). Hence, this sampling method started by identifying the first symptomatic CBS tree (tree 1) and numbering trees stepwise, moving away up (A) and down (C) within the row, collecting tissue from trees 2 (the tree next to tree 1 ), 4,8 , and 12 , for a total of nine trees (four tree A, four tree C, and tree 1). Another set of trees was selected by numbering trees moving away from tree 1 right (B) and left (D) across rows, and sampling trees 2, 3, 5, and 10 in each direction, for a total of eight trees (Fig. 1B). From 
each tree, eight mature leaves per quadrant (north, south, east, and west) were selected, for a total of 32 leaves per tree and a total of 17 trees per citrus grove, when possible. Collected materials were sent overnight to FDACS-DPI Section of Plant Pathology for analysis.

\section{Molecular analyses}

From each CBS-positive tree, up to seven symptomatic pieces of fruit were selected for analysis. Using a sterile scalpel, up to five fruit lesions in duplicate were extracted and pooled into a single 2-ml microcentrifuge tube. For leaf extractions, five to seven whole leaves were pooled into a single sample extraction bag (Agdia, Elkhart, IN, U.S.A.) containing 2.5 to $3 \mathrm{ml}$ of AP1 (Qiagen, Germantown, MD, U.S.A.) with $1 \mathrm{U}$ of RNAse. Soft superficial maceration was carried out using a Homex-6 tissue homogenizer (Bioreba, Reinach, Switzerland); then, an $800-\mu$ l aliquot of the extraction slurry was transferred onto a $2-\mathrm{ml}$ microcentrifuge tube (Supplementary Fig. S2A). For the quad tree sampling, approximately the same number of leaves were pooled per tree quadrant (north, south, east, and west) into single mesh bags containing 2.5 to $3 \mathrm{ml}$ of AP1 and, after scraping the leaf surface using the same homogenizer described above, 200 $\mu \mathrm{l}$ of leaf macerate was pooled into a single 2-ml microcentrifuge tube per tree (Supplementary Fig. S2B).

Fruit lesions and leaf macerates were disrupted in tissuelyser Mini Beadbeater 96+ (Biospec, Bartlesville, OK, U.S.A.) for $3 \mathrm{~min}$. DNA extraction was carried out using the

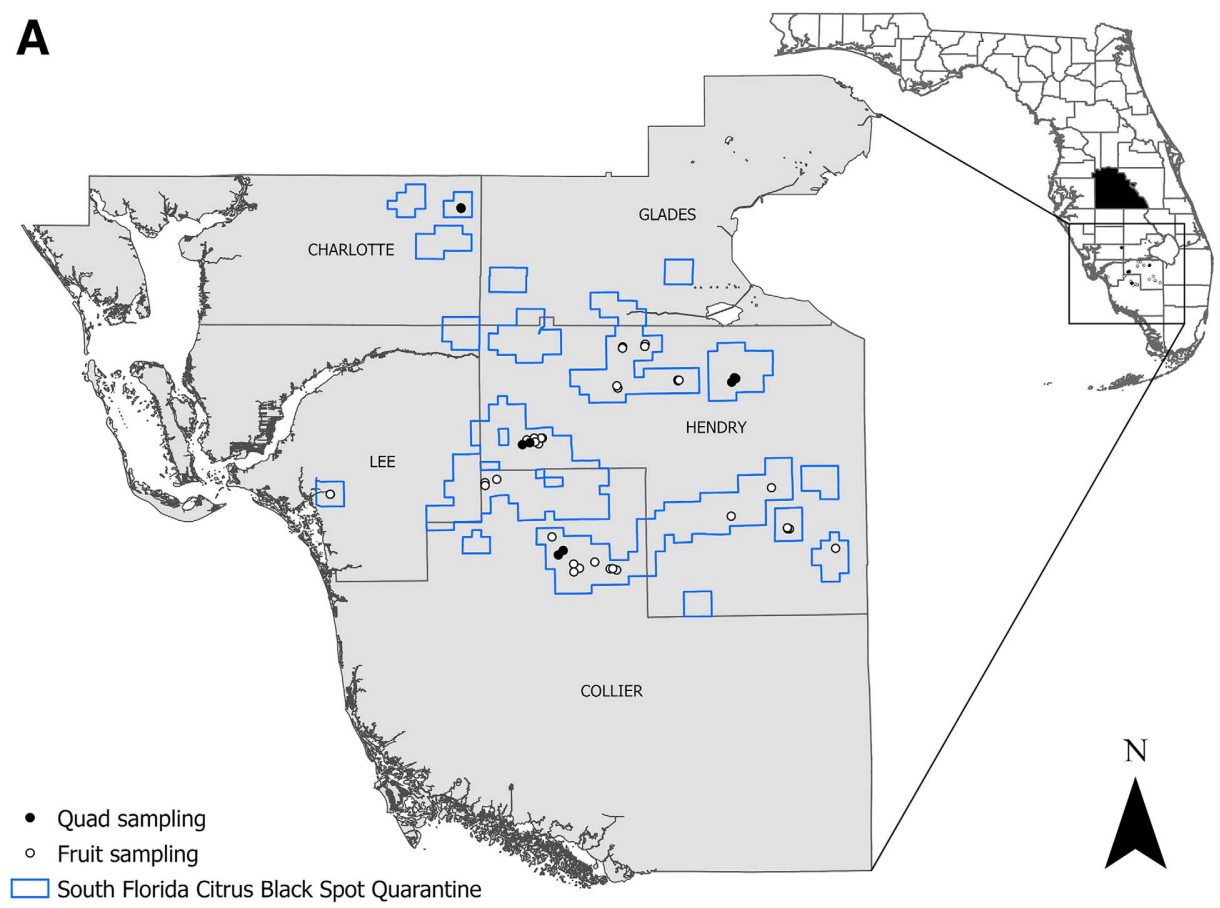

\section{B}

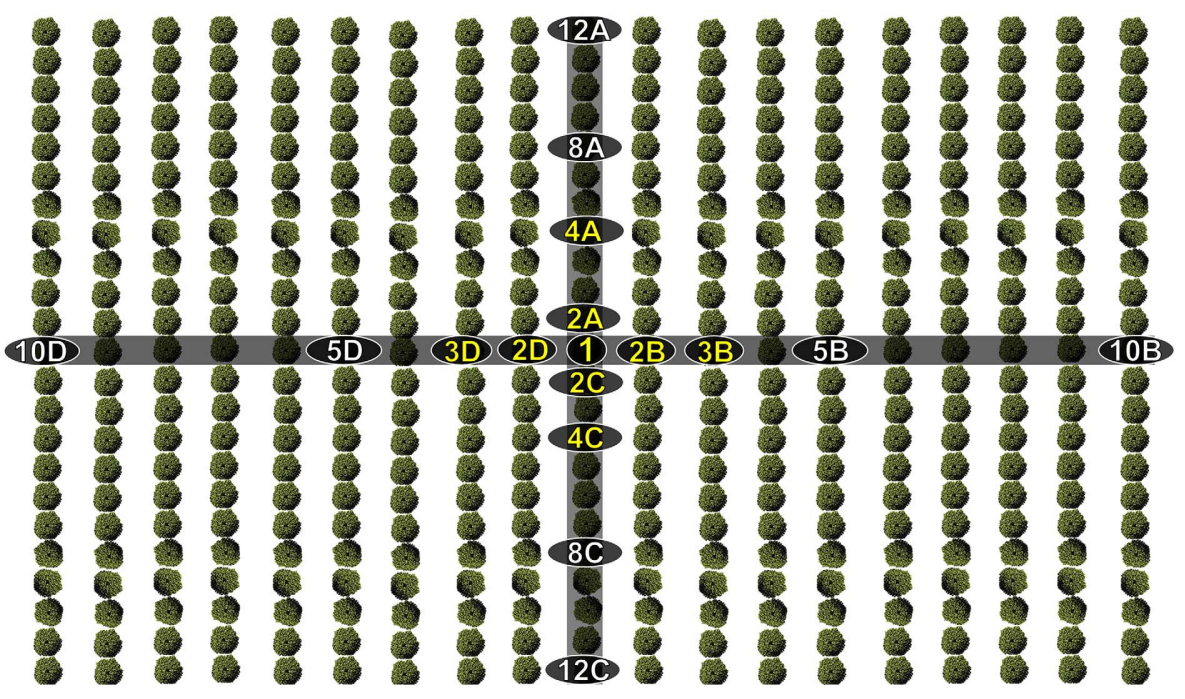

FIGURE 1

A, Map of southwest Florida showing the location of citrus groves selected in this study. Counties where citrus black spot (CBS) is present are shown in in light gray and Polk County, where CBS was detected only one time, is in black. B, Detail of the quad sampling. Trees in the interior (I) of the quad are shown in yellow with black background and exterior $(\mathrm{E})$ in black with white background. 
DNeasy Plant Mini kit (Qiagen, Germantown, MD, U.S.A.) following the manufacturer's protocol, with modification for a doubled volume of extraction buffer (McVay et al. 2019). Total DNA concentration was estimated using Nanodrop 2000 and software v.1.4.1 (Thermo Scientific, Waltham, MA, U.S.A.) (Supplementary Table S3) and the assessment of quality of the DNA extraction procedure was initially performed by the qPCR assay targeting the citrus pathogen ' $\mathrm{Ca}$. L. asiaticus' (McVay et al. 2019; Selvaraj et al. 2018), broadly distributed among groves in Florida, with all samples positive for this pathogen (Supplementary Table S4).

qPCR for detection of CBS targeting the ITS1 locus (qITS) was carried out using a previously published primers and probe set (Bonants et al. 2003; Van Gent-Pelzer et al. 2007): Gc-F forward primer 5'-GGTGATGGAAGGGAGGCCT-3', Gc-R reverse primer 5' -GCAACATGGTAGATACACAAGGGT-3', Gc-P probe 5'-FAM/AAAAAGCCG/ZEN/CCCGACCTACC TTCA/3IABkFQ/-3', and fluorophore reporter 6-carboxyfluorescein (FAM), double quenched with ZEN and Iowa Black FQ (3iABkFQ). Master mix components for the qPCR were set to a final concentration of $150 \mathrm{nM}$ each primer, $100 \mathrm{nM}$ probe, $1 \times$ SensiFast LoRox mastermix (Bioline Meridian Bioscience, Cincinnati, $\mathrm{OH}$, U.S.A.), and $3 \mu \mathrm{l}$ of total DNA completed with moleculargrade water for a $20-\mu l$ final volume. Reactions were carried out in a QuantStudio 5 Real-Time PCR System (Thermo Scientific) using the following thermal conditions: initial denaturation at $95^{\circ} \mathrm{C}$ for 3 min, followed by 40 cycles of denaturation at $95^{\circ} \mathrm{C}$ for $5 \mathrm{~s}$ and annealing and extension at $58^{\circ} \mathrm{C}$ for $40 \mathrm{~s}$.

We tested the performance of the qITS assay with the fluorophore reporter Cy5 (Thermo Scientific), double quenched with TAO and 3iABkFQ with no significant differences in cycle threshold $(\mathrm{Ct})$ values with respect to FAM (Supplementary Table S5), allowing us to perform a triplex qPCR assay (with MAT probes with fluorescent reporters FAM-MAT1 and VIC-MAT2) and adopt the same primers and probes into the dPCR assay (detailed in the next section) in mastermix reaction at the same concentration and volumes and with the following thermal conditions: initial denaturation at $95^{\circ} \mathrm{C}$ for $3 \mathrm{~min}$, followed by 40 cycles of denaturation at $95^{\circ} \mathrm{C}$ for $5 \mathrm{~s}$ and annealing and extension at $60^{\circ} \mathrm{C}$ for $20 \mathrm{~s}$.

\section{Standardization and validation of the mating type qPCR assay}

For the detection of each MAT idiomorph of $P$. citricarpa using a qPCR assay (qMAT), primer pairs and probes were designed using the OligoAnalyzer Tool (Integrated DNA Technologies 2018). Sequences are as follows: MAT1 (MAT1-1-1): MAT1-1-1F, primer forward, 5' -CAACATCTCGACCTCTCAT CT-3'; MAT1-1-1R, primer reverse, 5'-CTGGAGTTTGTGG AGTGGAATA-3'; and MAT1-1-1P, probe 5'-/FAM/TTCATC ATT/ZEN/CCAC CGCGACCACA/3BHQ_1/-3'; and MAT2 (MAT1-2-1): MAT1-2-1F, primer forward, 5'-CCAGAAGAAA TCGGAAGAGAGG'3'; MAT1-2-1R, primer reverse, 5'-GAG ACGGATGACCAAGAAGAAG-3'; and MAT1-2-1P, probe 5'-/VIC/TCGTCAGAA/TAO/AT CGAGGGCCTGTTG/3IA bRQsP/-3'; with fluorophore reporter Freedom (VIC) and double quenchers TAO and Iowa Black RQ (3IAbRQsP) (Supplementary Fig. S3). In silico analyses were performed to determine the specificity of the primers and probes using NCBI Primer-Blast online software (Ye et al. 2012). Positive controls of each mating type were synthesized from sequences obtained from GenBank (MAT1-1-1, 941 bp, KU852493; and MAT1-2-1, 1,463 bp, KU845489) (Amorim et al. 2017), avoiding any possibility of introduction of MAT1-1-1 into Florida. The performance of the qMAT assay alone and the triplex assay for ITS and MAT (qITS-MAT) were tested using different annealing temperatures and source of DNA as qPCR master mix components at a final concentration of $150 \mathrm{nM}$ primer pairs, $100 \mathrm{nM}$ probes, $1 \times$ SensiFAST Probe Lo-ROX kit $2 \times$ (Bioline Meridian Bioscience, Cincinnati, OH, U.S.A.), and $3 \mu$ l of total DNA (with different sources and concentrations of MAT synthetic idiomorph mixture; $P$. citricarpa pure DNA spiked with MAT1-1-1 or pure citrus DNA spiked with MAT synthetic idiomorph mixture) completed with sterile double-distilled water up to $20 \mu \mathrm{l}$ of final volume. Reactions were carried out under the following conditions: initial denaturation at $95^{\circ} \mathrm{C} \mathrm{C}$ for $3 \mathrm{~min}$, and 40 cycles of denaturation at $95^{\circ} \mathrm{C}$ for $5 \mathrm{~s}$ and, annealing and extension at 54, 56, 58, 60, 62, and $64^{\circ} \mathrm{C} \mathrm{C}$ for $40 \mathrm{~s}$ (Fig. 2).

After optimizing annealing temperature for the qMAT and qITS-MAT assays (Fig. 2), validation was addressed by testing on Phyllosticta spp. isolated from diverse plant hosts in Florida: isolates were identified using ITS markers following previously standardized protocols by Urbina and Aime (2018) and White et al. (1990) (Supplementary Table S6) and generating a standard curve from 10-fold serial dilutions of synthetic MAT idiomorphs, pure DNA of $P$. citricarpa spiked with synthetic MAT1, and citrus DNA spiked with synthetic MAT idiomorphs; all variants were tested in triplicate (Fig. 3).

We tested for potential inhibition caused by clean-citrus DNA concentration obtained from healthy nursery seedling leaves routinely certified in our laboratory (hereafter "citrus DNA"), using the aforementioned extraction protocol for canopy leaves, with three final elution volumes $(50,100$, and 200 $\mu \mathrm{l})$ and five different volumes into the PCR from 1 to $5 \mu \mathrm{l}$ of total citrus DNA spiked with synthetic MAT1 and MAT2 idiomorphs (Supplementary Fig. S4A to C).

Throughout all PCR runs, a set of controls was established (in duplicate) as positive (total DNA extracted from a pure culture of $P$. citricarpa spiked with synthetic MAT1), blank (free-of-pathogen citrus DNA, with the expected undetermined result), and no-template control (NTC) (containing water instead of DNA, with the expected undetermined result).

\section{Standardization and validation of dPCR targeting ITS and MAT idiomorphs of $P$. citricarpa}

We standardized dPCR assays separately for $P$. citricarpa targeting ITS (dITS) and mating types (dMAT) in the QuantStudio 3D Digital PCR system (Thermo Scientific) because this platform only detects two fluorophore reporters (FAM and VIC). We determined the performance of both assays at different annealing temperatures and using different DNA sources (as above) (Fig. 4) in reactions containing $100 \mathrm{nM}$ primers and probes, $1 \times$ QuantStudio 3D Digital PCR Master Mix v2, $3 \mu$ of DNA template, and sterile double-distilled water up to $14.50 \mu \mathrm{l}$ of final volume. Mastermix reactions were loaded onto Digital PCR Chip v2 using the Digital PCR Chip Loader following the manufacturer's protocol. PCR assays were run in the ProFlex $2 \times$ Flat PCR System (or Dual Flat Block GeneAmp PCR System 9700) with initial DNA denaturation at $96^{\circ} \mathrm{C}$ for $10 \mathrm{~min}$, followed by 40 cycles of DNA denaturation at $98^{\circ} \mathrm{C}$ for $30 \mathrm{~s}$, annealing at $60^{\circ} \mathrm{C}$ for $2 \mathrm{~min}$, and hold at $10^{\circ} \mathrm{C}$. Chips were then analyzed using the QuantStudio 3D Digital PCR Instrument along with the online QuantStudio AnalysisSuite v3.0 using predetermined parameters (http://www.thermofisher. com/). Throughout all PCR runs, three chips were designated as controls (positive, blank, and NTC), as mentioned above for the qPCR assays. 
We addressed the computation of the limit of blank (LoB, maximum false positive when target DNA is absent), limit of detection (LoD, lowest concentration of target DNA reliably discriminate from the blank), and limit of quantification (LoQ, lowest concentration of target DNA reliably quantifiable under specific assay) following the parametric methodology proposed by Armbruster and Pry (2008). The LoB was determined by testing 20 chips without target DNA and the LoD was determined by testing both DNA from pure culture of $P$. citricarpa and MAT synthetic idiomorph mixture at a concentration of approximately 20 copies into $14.50 \mu \mathrm{l}$ of reaction and the computation were extrapolated to the theoretical approximately 4 copies/reaction. Finally, LoQ was determined by testing both DNA from pure culture of $P$. citricarpa and the MAT idiomorph mixture in 10-fold serial dilution (in quintuplicate). In each experiment, reactions were spiked with $5 \mu \mathrm{l}$ of citrus DNA (eluted in a 200- $\mu$ l final volume) (Supplementary Fig. S4B to D).

Validation of the dITS and dMAT assays was performed by comparison with qPCR $(\mathrm{Ct})$ values (from qITS-MAT) and copy numbers per microliter of DNA extracted from fruit lesions and synthetic MAT idiomorphs (in triplicate) (Fig. 4B). For quad sampling, leaf DNA was pooled by grove and by the location of the trees with respect to the

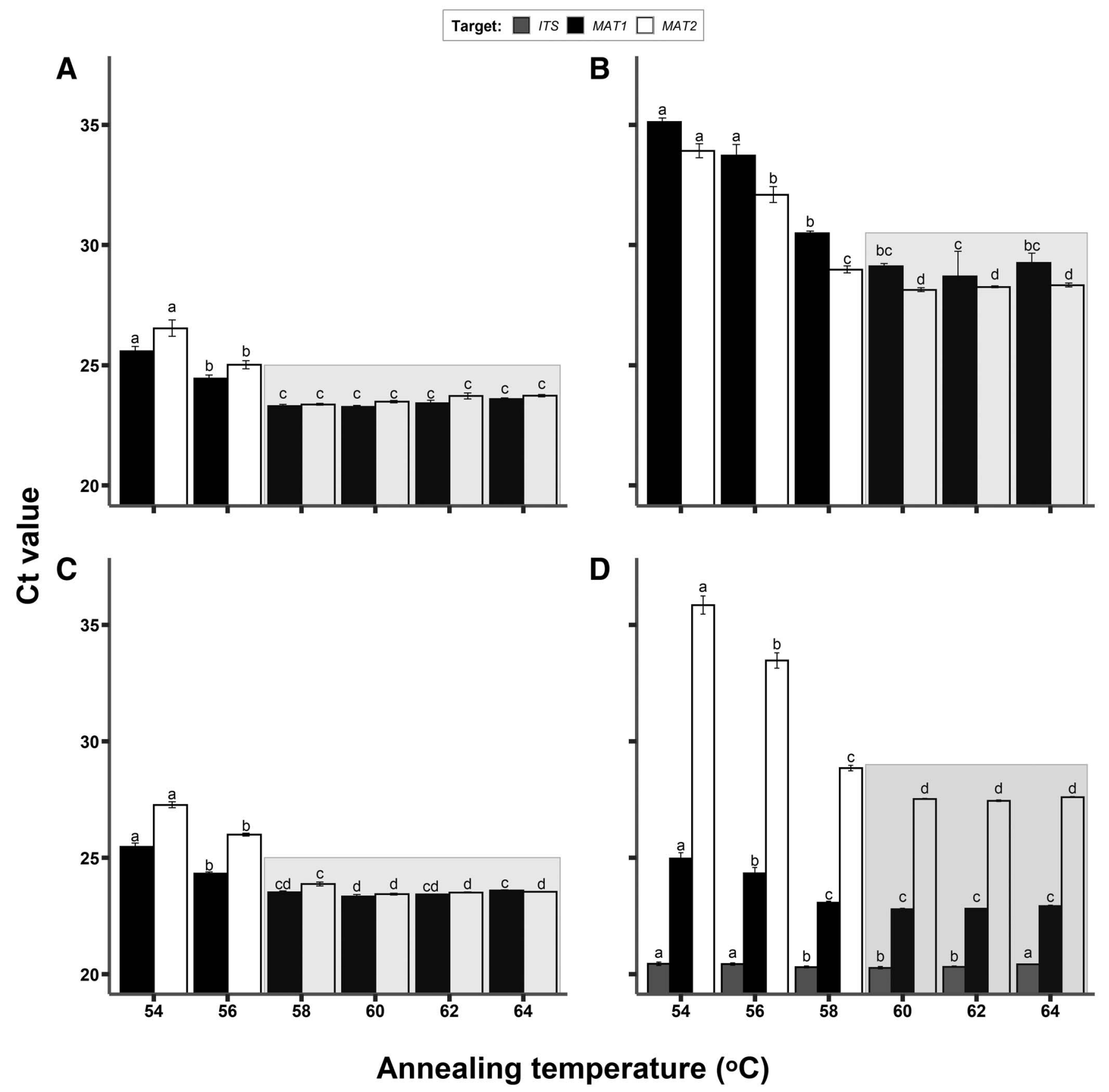

FIGURE 2

Evaluation of the performance of the quantitative PCR assay for the detection of each MAT idiomorph under different annealing temperatures and DNA source. A, Synthetic MAT idiomorphs; B, DNA from pure culture of Phyllosticta citricarpa spiked with synthetic MAT1; C, citrus DNA spiked with synthetic MAT idiomorphs; and D, triplex assay using DNA from pure culture of $P$. citricarpa spiked with synthetic MAT1. Shaded bars highlight no significant variation in cycle threshold (Ct) values among trials. 
CBS-positive tree (center of the quad) as trees 1 to 4 , quad interior (I), and 5 to 12 , quad exterior (E). DNA pools were individually tested in duplicate in qITS-MAT and in quadruplicate on dITS. To confirm the presence of only MAT2 in Florida using dMAT, DNA obtained from CBS fruit lesions and leaves collected at the same grove were pooled and tested in triplicate.

Statistical significance of the evaluation of the performance of the qMAT, qITS-MAT, dMAT, and dITS assays under different temperatures and DNA sources was evaluated by applying confidence intervals (CIs) and Tukey's test. The test one-way analysis of variance was used to assess statistical significance of the variation among $\mathrm{Ct}$ values and copies per microliter across replicates of varying concentrations and volumes of citrus DNA added to the qMAT and dMAT assays, as well as variation among $\mathrm{Ct}$ values between simplex and triplex qPCR assays when different reporter dyes were used for the same probe. All tests and plots were performed in R v3.6.3 (Ripley 2001), using the libraries ggplot2 v.3.3.2 (Wickham 2016) and vegan v2.5-6 (Oksanen et al. 2007).

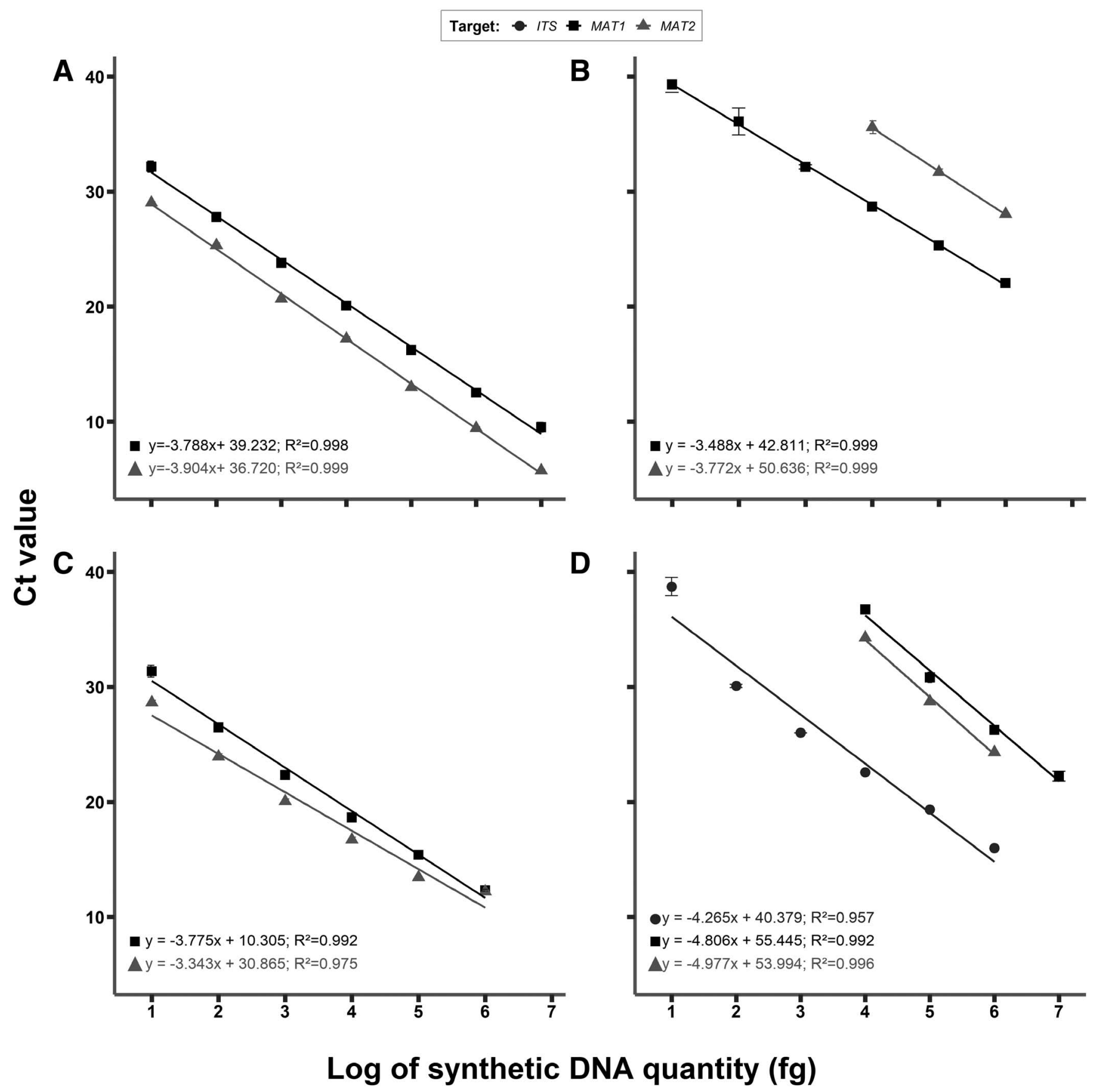

FIGURE 3

Evaluation of the performance of quantitative PCR assay for the detection of each MAT idiomorph using serial DNA dilutions of $\mathbf{A}$, synthetic MAT idiomorphs; B, DNA from pure culture of Phyllosticta citricarpa spiked with synthetic MAT1; C, citrus DNA spiked with synthetic MAT idiomorphs; and D, triplex assay using DNA from pure culture of $P$. citricarpa spiked with synthetic MAT1. Ct $=$ cycle threshold. 


\section{RESULTS}

\section{Sensitivity and specificity of qPCR assay for mating types of $P$. citricarpa}

Based on results of annealing temperature optimization, we selected $60^{\circ} \mathrm{C}$ as the optimal temperature for both qMAT and qITS-MAT; however, the annealing temperature
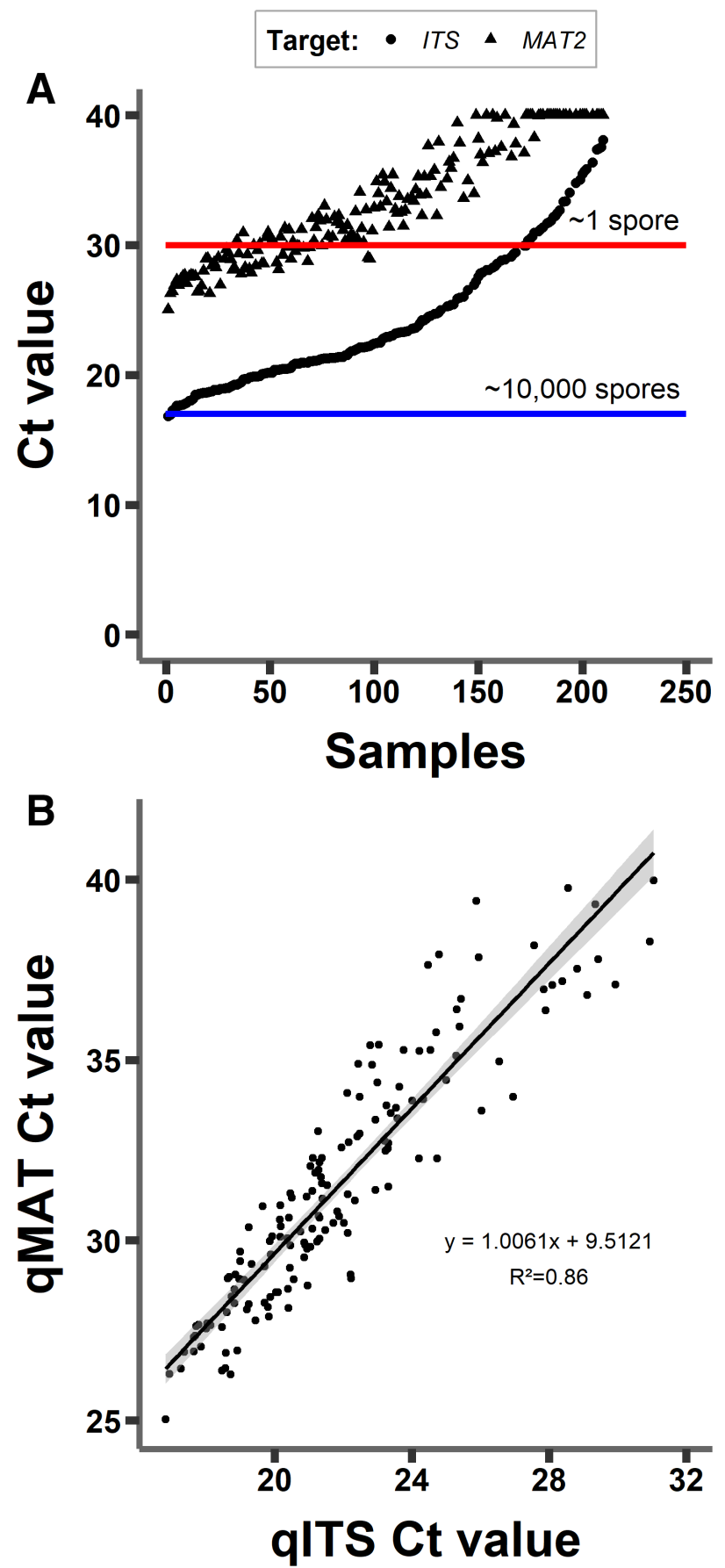

FIGURE 4

A, Difference in sensitivity between quantitative PCR assays for the detection of each MAT idiomorph and detection of citrus black spot targeting the internal transcribed spacer (ITS) locus using DNA from fruit lesions and leaves and $\mathbf{B}$, correlation between assays using only positive samples. $\mathrm{Ct}=$ cycle threshold. can be adjusted up to $64^{\circ} \mathrm{C}$ without any significant difference in cycle quantification $(\mathrm{Ct})$ values (Fig. 2). At lower annealing temperatures (54 and $56^{\circ} \mathrm{C}$ ), assay performance was suboptimal, likely due to nonspecific primer binding (Fig. 2).

The specificity of the qMAT and qITS-MAT assays for $P$. citricarpa was tested against 13 Phyllosticta spp. isolated from Florida from diverse hosts, with no amplification in any noncitricarpa species (GenBank accession numbers MT649656 to MT649668) (Supplementary Table S6). Standard curves using 10-fold serial dilutions of synthetic MAT idiomorphs, pure DNA of $P$. citricarpa spiked with synthetic MAT1, and citrus DNA spiked with synthetic MAT idiomorphs showed a linear range over six orders of magnitude to $10 \mathrm{fg}$ of total targeting DNA, and no significant change in performance of the assay by the presence of citrus DNA obtained from leaves (Fig. 3). We did not detect any nonspecific amplification in citrus DNA (blank) for assays qMAT and qITSMAT (data not shown).

\section{CBS in southwest Florida}

In this study, the concentration of total DNA extraction from five fruit lesions varied from 4.00 to $113.90 \mathrm{ng} / \mu \mathrm{l}$ (mean = $24.87 ; \mathrm{CI}=8.52, n=30$ ) with the ratio of absorbance at 260 and $280 \mathrm{~nm}(260 / 280$ ratio) ranging from 1.22 to 2.05 (mean = 1.66$, CI $=0.07)$ (Supplementary Table S3). Variation of the DNA concentration was attributed to maturity of the pathogen pycnidia. We tested for the presence of $P$. citricarpa and its mating types in 229 individual fruit from 36 different trees in groves located in the counties under CBS quarantine in southwest Florida. As a result of that testing, 10 groves, 50 citrus blocks, and Charlotte County were added to the quarantine during the 2018-19 citrus harvesting season (Supplementary Table S1). The protocol for DNA extraction and the qITS-MAT assay designed here were effective at both detection of $P$. citricarpa, recovered from $100 \%$ of the fruit examined $(\mathrm{Ct}$ values $=16.82$ to 38.11 ), and the mating type MAT2, recovered in $83.2 \%$ of the samples examined ( $\mathrm{Ct}$ values $=25.03$ to 38.28$)$; MAT1 was not detected in any sample tested (Fig. 4A). It is important to mention that we did not find any CBS-positive fruit from Polk County and other counties out of the quarantine zone (e.g., Osceola and Lake) from where we examined fruit containing suspected CBS lesions (data not shown).

$\mathrm{Ct}$ values of the qMAT assay were always higher than the qITS assay, with a difference, on average, of $9.55(\mathrm{CI}=0.2)$ (Fig. 4A), a result consistent with the multicopy presence of ribosomal RNA genes versus a single copy of the mating type in spores of $P$. citricarpa. This also explains why, in some cases, we could not detect the mating type in some fruit lesion samples, and the inability to detect the mating type in leaves, where the pathogen is in much lower abundance. The expected correlation between qITS and the qMAT was observed (Fig. 4B), confirming the reliability of our results.

The concentration obtained of total DNA from asymptomatic citrus varied from 4.00 to $459.00 \mathrm{ng} / \mu \mathrm{l}$ (mean $=92.13 \mathrm{ng}$ / $\mu \mathrm{l}, \mathrm{CI}=44.05, n=30$ ) while the $260 / 280$ ratio ranged from 0.83 to 1.69 (mean $=1.14, \mathrm{CI}=0.09)$ (Supplementary Table S4). The higher variation in concentration among samples was attributed to operator error (pressing too hard on the leaf surface) with a consequence of lower 260/280 ratio than fruit. We successfully detected $P$. citricarpa from leaves collected adjacent to infected fruit in 10 of 22 infected trees; the lower detection rate $(46 \%)$ compared with that in symptomatic fruit can be attributed to the lower amount and uneven distribution 
of inoculum. Of these, mating type (both MAT2) was recovered in three samples $(\mathrm{Ct}$ values $=32.27,36.96$, and 37.08) (Supplementary Table S1).

Knowing that we could detect $P$. citricarpa from asymptomatic leaves, we tested whether we could detect the pathogen in asymptomatic trees close to a CBS-positive tree (Supplementary Table S2). We detected CBS in four of nine citrus groves tested, including the two known CBS-positive groves (used as a positive control) (Supplementary Table S2). In sum, the majority of the CBS-positive trees were found close to the center of the quad (12 of 14 trees) (Table 1), consistent with the low dispersal ability of the asexual state of $P$. citricarpa. Also, we could not detect CBS in one positive grove (9G) where the CBS-positive tree (center of the quad) was present, consistent with the uneven distribution and low inoculum of the asexual state of $P$. citricarpa in a single tree. Our results showed that, using the qITS assay, it is possible to detect $P$. citricarpa in asymptomatic leaves in a quad sampling, in concordance with previous studies in Brazil, and without a previous incubation or enrichment procedure (Faganello et al. 2017). It is important to mention that the citrus groves selected for this part of our study were under different management regimes and sampling was carried out at different dates throughout the citrus harvesting season of 2018-19; hence, with different pathogen inoculum, methodological issues restricted further inferences.

TABLE 1

Comparison of sensitivity of quantitative and digital PCR assays for detection of citrus black spot (CBS) targeting the internal transcribed spacer locus from leaves adjacent to the CBS-infected fruit ${ }^{\mathrm{a}}$

\begin{tabular}{|c|c|c|c|c|}
\hline Grove $^{b}$ & Cycle threshold & Copies per microliter & \pm Confidence interval & Precision $(\%)^{\mathrm{d}}$ \\
\hline \multicolumn{5}{|c|}{$\begin{array}{l}\text { Leaves }(C) \text { adjacent to } \\
\text { infected fruit }\end{array}$} \\
\hline 3 & 27.84 & 379.21 & 9.34 & 2.46 \\
\hline 4 & 29.94 & 44.38 & 2.17 & 4.88 \\
\hline 5 & 28.26 & 206.05 & 5.29 & 2.57 \\
\hline 6 & Undetected & 3.81 & 0.83 & 21.77 \\
\hline 11 & Undetected & 0.90 & 0.59 & 65.88 \\
\hline 12 & Undetected & 5.19 & 1.37 & 26.40 \\
\hline 14 & 34.84 & 5.79 & 1.18 & 20.35 \\
\hline 15 & Undetected & 1.48 & 0.58 & 39.28 \\
\hline 17 & Undetected & 0.67 & 0.43 & 63.23 \\
\hline 18 & Undetected & 0.85 & 0.47 & 55.00 \\
\hline 21 & Undetected & 3.86 & 0.85 & 21.90 \\
\hline 24 & Undetected & 0.74 & 0.81 & 109.76 \\
\hline 27 & 33.34 & 3.58 & 0.79 & 22.15 \\
\hline 30 & Undetected & 0.87 & 0.60 & 68.85 \\
\hline 32 & Undetected & 0.58 & 0.38 & 65.88 \\
\hline \multicolumn{5}{|c|}{ Quad sampling } \\
\hline $1 \mathrm{G}-\mathrm{I}$ & Undetected & 1.09 & 0.40 & 36.33 \\
\hline $1 \mathrm{G}-\mathrm{E}$ & Undetected & 1.82 & 0.59 & 32.31 \\
\hline 2G-I & Undetected & 0.33 & 0.22 & 65.88 \\
\hline 2G-E & Undetected & 0.25 & 0.31 & 122.59 \\
\hline 3G-I & Undetected & 1.15 & 0.39 & 33.93 \\
\hline $3 \mathrm{G}-\mathrm{E}$ & Undetected & 0.86 & 0.32 & 37.43 \\
\hline 4G-I & Undetected & 0.81 & 0.34 & 41.41 \\
\hline $4 \mathrm{G}-\mathrm{E}$ & Undetected & 0.36 & 0.23 & 63.23 \\
\hline 5G-I & Undetected & 1.09 & 0.40 & 36.33 \\
\hline $5 \mathrm{G}-\mathrm{E}$ & Undetected & 0.83 & 0.30 & 35.81 \\
\hline 6G-I & Undetected & 0.66 & 0.27 & 40.66 \\
\hline $6 \mathrm{G}-\mathrm{E}$ & Undetected & 0.57 & 0.35 & 60.86 \\
\hline 7G-I & 31.52 & 6.54 & 0.87 & 13.25 \\
\hline 7G-E & Undetected & 12.10 & 1.58 & 13.03 \\
\hline 8G1-I & 31.08 & 1.09 & 0.40 & 36.33 \\
\hline 8G1-E & Undetected & 10.03 & 1.16 & 11.58 \\
\hline $8 \mathrm{G} 2-\mathrm{I}$ & Undetected & 0.71 & 1.03 & 45.82 \\
\hline 8G2-E & Undetected & 3.14 & 3.79 & 20.55 \\
\hline 9G1-I & Undetected & 1.69 & 0.40 & 23.54 \\
\hline 9G1-E & Undetected & 9.66 & 1.08 & 11.22 \\
\hline 9G2-I & Undetected & 4.60 & 1.12 & 20.01 \\
\hline 9G2-E & Undetected & 1.44 & 1.93 & 33.51 \\
\hline
\end{tabular}

${ }^{a}$ Positive samples are indicated in bold.

${ }^{\mathrm{b}}$ Details of citrus groves are in Supplementary Table S1.

${ }^{\mathrm{c}}$ Concentration of the ITS loci of all positive samples were above the limit of detection (LoD) computed here.

d "Precision refers to the ability to distinguish between two measurements (such as sample concentrations) with a certain confidence, so precision is used to express the tightness of the CI, the lower the precision, the tighter the Cl" (http://www.thermofisher.com). Samples in bold were considered positive in digital PCR (precision < 25\%).

${ }^{\mathrm{e}}$ Composite sample. Quad interior $=\mathrm{I}$, trees 1, 2A, 2B, 2C, 2D, 3B, 3D, 4A, and 4C; and quad exterior = E, trees 5B, 5D, 8A, 8C, 10B, 10D, 12A, and 12C. Samples were tested in quintuplicate. Groves ( $8 \mathrm{G}$ and $9 \mathrm{G}$ ) where the CBS-positive tree was present were collected during and after citrus harvesting season 2019-19 (1) and recollected after the citrus harvesting season ended (2); in the rest of the groves, the CBS-positive tree was removed or resent. 


\section{dPCR for detection of $P$. citricarpa and its mating types}

We successfully standardized protocols for detection of both ITS and MAT idiomorphs of $P$. citricarpa from fruit lesions and asymptomatic leaves on the dPCR platform, setting the optimal annealing temperature at $60^{\circ} \mathrm{C}$ for both assays (Fig. 5). Importantly, increasing the annealing temperature produced a profound decrease in the efficiency of assays at temperatures higher than $60^{\circ} \mathrm{C}$, contrary to the effect observed in the qPCR. At low annealing temperatures from 54 to $58^{\circ} \mathrm{C}$, the efficiency of the dMAT assay was the same as at $60^{\circ} \mathrm{C}$ (Fig. 5).

The LoB was determined to be 0.79 (ITS), 0.66 (MAT1), and 0.46 (MAT2) copies/ $\mu$ for each target. As expected, the LoD was slightly higher than LoB in all assays at 0.93 (ITS), 0.71 (MAT1), and 0.47 (MAT2) copies/ $\mu$ l, and higher LoQ was estimated at 6.71 (ITS), 2.50 (MAT1), and 5.17 (MAT2) copies/ $\mu \mathrm{l}$, set at $25 \%$ coefficient of variation as suggested by (Milosevic et al. 2018) (Fig. 6). To estimate the LoD of the qITS and qMAT assays, we used DNA at a low concentration

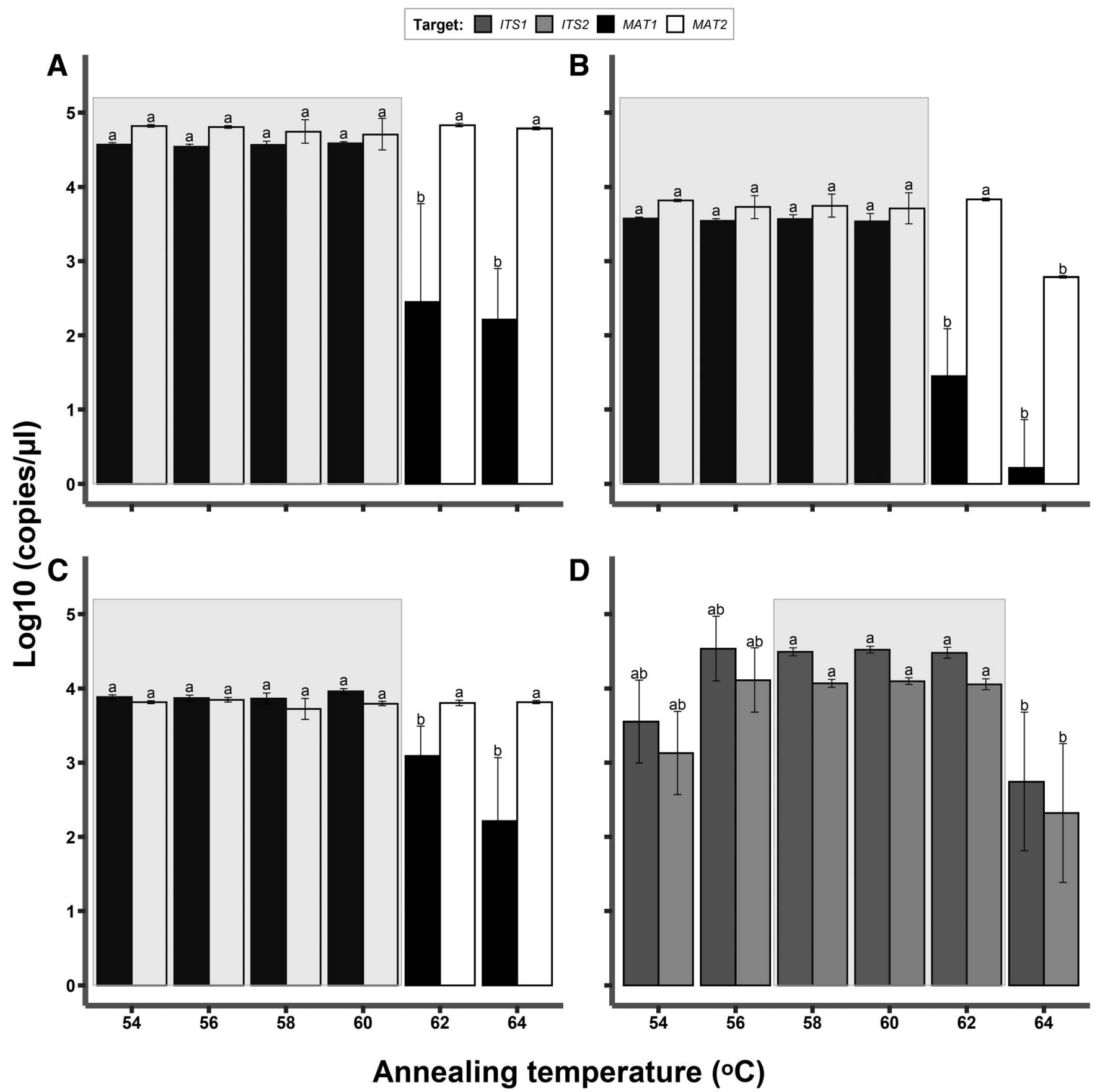

FIGURE 5

Evaluation of the performance of digital PCR (dPCR) assays targeting mating types under different annealing temperatures and DNA sources. A, Synthetic MAT idiomorphs (MAT1, black bars; MAT2 white bars); B, DNA from pure culture of Phyllosticta citricarpa spiked with synthetic MAT1; C, citrus DNA spiked with synthetic MAT idiomorphs; and D, dPCR assay targeting the internal transcribed spacer (dITS) using DNA from pure culture of $P$. citricarpa, alone (dark gray bars) and spiked with citrus DNA (light gray bars). Shaded bars highlight no significant variation in cycle threshold values among trials. 
of target Ct (approximately 38), with estimated target concentration of approximately 2 copies/ $\mu$; at this low target concentration, inhibitors in the DNA extracts obscured results.

The expected exponential correlation between $\mathrm{Ct}$ values (qPCR) and copies per microliter (dPCR) for both ITS and MAT2 loci, as well as the expected copy number disparity between ITS and MAT2, was observed in assays of DNA extracted from fruit lesions (Fig. 7). Using dPCR, we also estimate the proportion of copies of ITS versus MAT2 locus per nucleus at $52 \pm 6.35$, and $1 \pm 0.43(n=6)$ using pure DNA extracted from the $P$. citricarpa strain present in Florida; a similar number of ITS copies per nucleus (30 to 50) were reported by $\mathrm{Hu}$ et al. (2014).

We did not detect any copies of MAT1 in any of the composite CBS fruit lesions tested, consistent with previously published results and in support of the single mating type present in Florida (Supplementary Fig. S4). From a subset of asymptomatic leaves (based on the qITS assay) collected next to CBS-positive fruit $(n=17)$, we confirmed the reliability of the dPCR assay (agreement between qPCR and dPCR assays results) and were able to detect $P$. citricarpa in an additional three groves where the pathogen was presumably below the LoD of the qITS assay when inhibitors in the reactions obstructed PCR amplification (Table 1). Also, the superiority of the digital platform was further demonstrated in the quad sampling, in which $P$. citricarpa was detected in an additional seven samples (negative for the pathogen in qPCR) (Table 1), demonstrating that the $\mathrm{APCR}$ is the ideal platform for detection of CBS from leaves in asymptomatic citrus groves.

\section{DISCUSSION}

During the citrus harvesting season of 2018-19, we employed the qPCR and dPCR protocols standardized here to monitor the distribution and mating types of $P$. citricarpa in the citrus-producing area in southwest Florida, mostly in Valencia sweet orange blocks. Our results confirmed the presence of CBS in four counties (Charlotte, Collier, Hendry, and Lee) (Fig. 1) as of July 2019, using DNA extracted from fruit lesions from 36 citrus groves that resulted in 50 blocks added to the quarantine, including one residential property. From the same samples, we also confirmed the presence of only one mating type (MAT2) of $P$. citricarpa in Florida, results that are in accordance with previous studies supporting the maintenance and monitoring of the quarantine area-and its annual expansions-because the pathogen is reproducing exclusively asexually while dispersing mainly by water splash, and on field workers and machinery (Dewdney et al. 2016; Hendricks et al. 2017; Tran et al. 2017; Wang et al. 2016). The standardization of $\mathrm{qPCR}$ and $\mathrm{dPCR}$ protocols for detection of $P$. citricarpa from leaves is a significant advancement in the
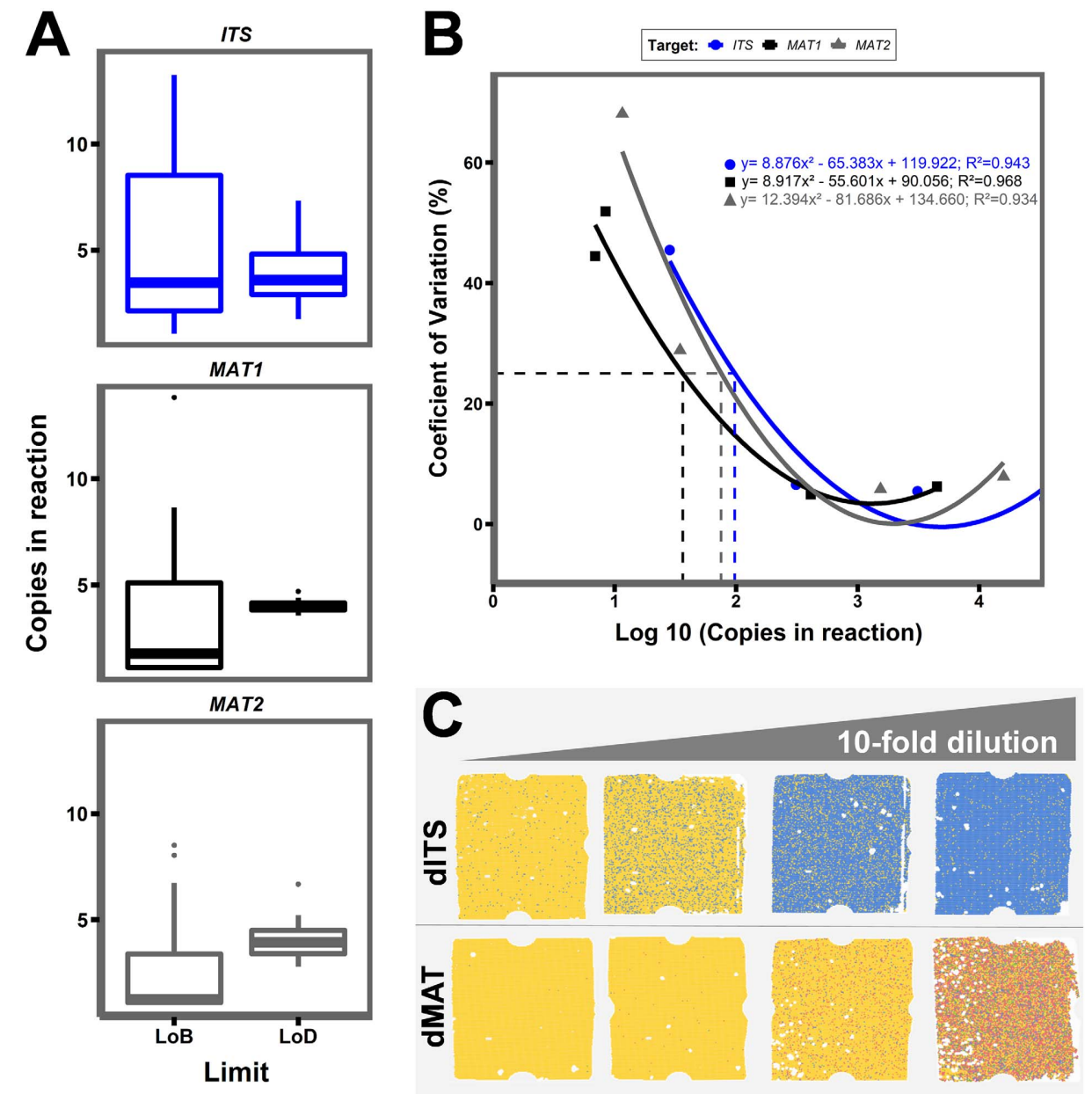

FIGURE 6

A, Limit of blank and of detection and B and C, limit of quantification for digital PCR assays targeting the internal transcribed spacer (dITS) and mating types (dMAT) assays with $25 \%$ coefficient of variation. 
monitoring of $P$. citricarpa in Florida, because this strain produces inconspicuous leaf lesions, limiting techniques for field monitoring to visualization of fruit lesions. The leaf collection methodology is easy to perform by inspectors in the field and is followed with a relatively easy protocol for DNA extraction. We demonstrate that molecular detection of $P$. citricarpa is possible from leaves taken next to symptomatic fruit as well as from adjacent, asymptomatic trees; collected from different production blocks under a range of different management regimes; and overcoming high concentration of PCR inhibitors on the citrus leaves, including copper, a compound broadly applied in the agroindustry to control bacterial and fungal diseases (Matheson et al. 2009; Selvaraj et al. 2018). This finding is in line with previous studies that reported P. citricarpa on asymptomatic citrus tissue such as leaves, fruit, twigs, petioles, soil, and leaf litter (de Oliveira Silva et al. 2017; Faganello et al. 2017; Meyer et al. 2012; Wang et al. 2016; Zhang 2017), as well as its preferential infection of fruit, only producing leaf lesions when trees are under stress or when leaves are dying (Hendricks et al. 2020; Tran et al. 2017).

It is important to mention that sister species to $P$. citricarpa that also occur on citrus (such as $P$. paracitricarpa Guarnaccia \& Crous, $P$. paracapitalensis Guarnaccia \& Crous, and P. citriasiana Wulandari, Crous \& Gruyter, among other undescribed species) with identical or almost identical ITS sequences can be amplified using the primers and probes developed by Bonants et al. (2003) and Van Gent-Pelzer et al. (2007) for detection of P. citricarpa (Schirmacher et al. 2019); however, no occurrence of any $P$. citricarpa sister species has been confirmed in Florida. Hence, it is unlikely that our results from leaves were affected by the amplification of other nontargeted Phyllosticta spp. Our protocol for extraction of DNA from leaves standardized here uses only extracts obtained from scraping the surface of citrus leaves, reducing the possibility of bringing endophytic Phyllosticta spp. immersed in the mesophyll tissues. We have observed nonspecific amplification of the Bonants et al. (2003) and Van Gent-Pelzer et al. (2007) assay on very few occasions from DNA obtained from both fruit lesions and canopy leaves (qPCR $\mathrm{Ct}$ value approximately 16; data not shown), while there was no amplification of either $P$. citricarpa mating type in these samples, which allowed rapid detection of these misleading results. Recently, improved species-specific primers for qPCR detection of $P$. citricarpa (that avoid the amplification of $P$. citriasiana) were developed by Schirmacher et al. (2019); in future work, we will further examine the materials presented here to assess the presence of these cryptic congeners.

Two common dPCR platforms, the QuantStudio 3D system and the Bio-Rad Droplet Digital PCR (ddPCR) system (Hercules, CA, U.S.A.), allow for the amplification of low copy sequences in the presence of inhibitors, making them ideal platforms for diagnosis of pathogens with low inoculum (Dreo et al. 2014; Laig et al. 2020; Zhong et al. 2018). Here, we demonstrated the greater sensitivity of dPCR in molecular diagnosis of CBS in comparison with qPCR through the increased detection rate of $P$. citricarpa from asymptomatic leaves collected next to CBS-infected fruit as well as on asymptomatic trees in CBS-positive citrus groves. Currently, the cost per sample of the dPCR is much higher than qPCR, and even higher when the target is in low concentration, because multiple replicates are necessary to generate reliable

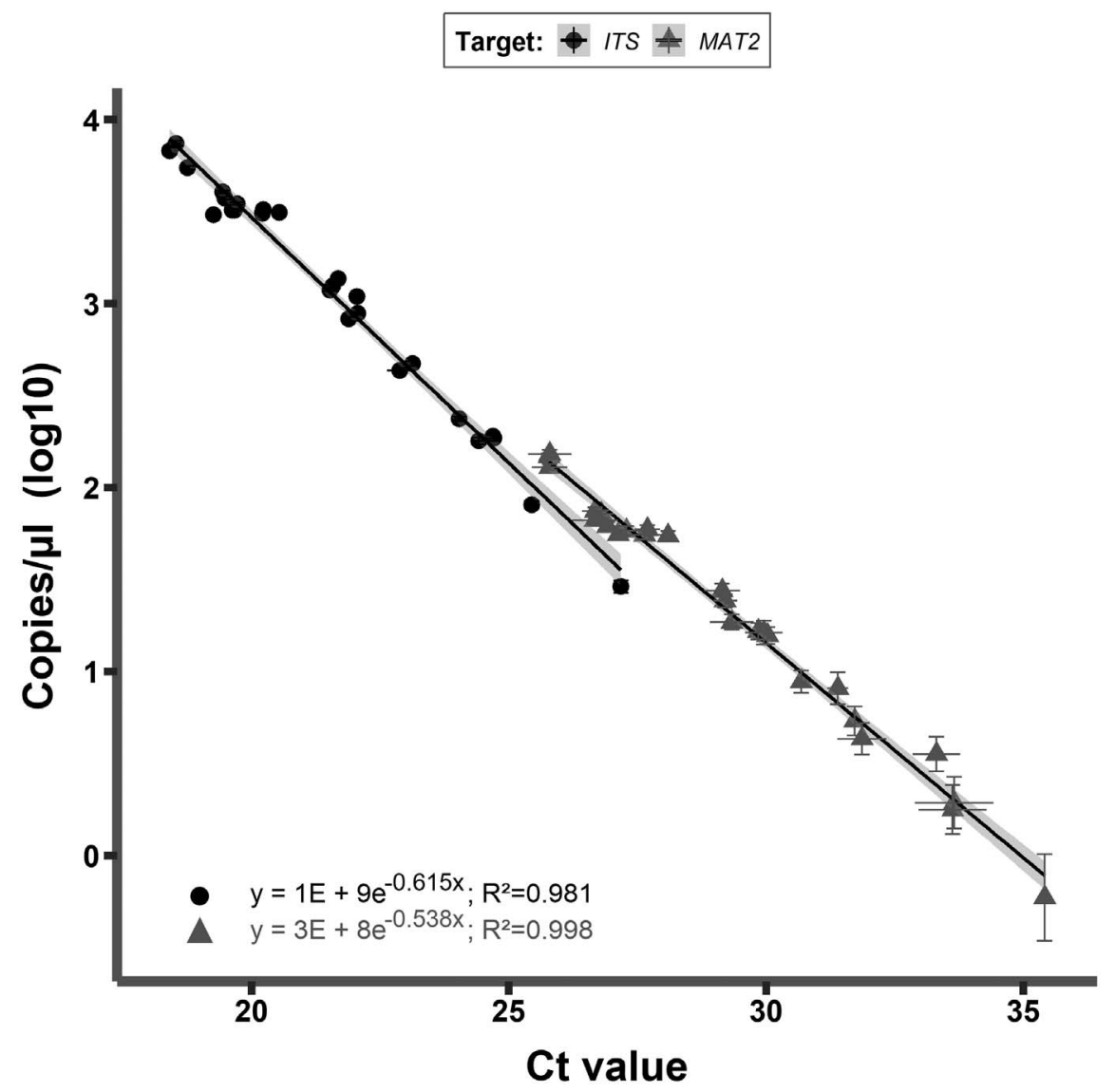

FIGURE 7

Relationship between results of the quantitative (cycle threshold [Ct] value) and digital assays (copies per microliter) of the internal transcribed spacer (ITS) and MAT2 loci using composite DNA from fruit lesions and leaves. 
results. Additionally, dPCR on the QuantStudio 3D requires that each sample be processed individually, greatly increasing the labor hours per sample, and requiring a greater degree of technical skill in order to obtain accurate results. These drawbacks, however, have not impeded the standardization of molecular assays for detection of many targets in the medical and food safety sectors (Karlin-Neumann and Bizouarn 2018) and, more recently, in agricultural applications (Bahder et al. 2018). Additionally, new protocols for detection of plant pathogens have been standardized in ddPCR; for example, Xylella fastidiosa Wells (Dupas et al. 2019) and ' $\mathrm{Ca}$. L. asiaticus' (Zhong et al. 2018). This platform has superior multiplexing capabilities when compared with dPCR; however, initial investment may be prohibitive. Hence, we believe that dPCR is currently the more cost-effective technology for small plant diagnostic clinics.

CBS is considered a major plant disease affecting groves in many regions of the world, significantly diminishing global citrus production. To date, scientific studies have aimed to characterize and understand the biology of $P$. citricarpa and its relatives using both classical morphology (Glienke et al. 2011; van der Aa 1973) and molecular techniques and, most recently, employing whole-genome comparisons (Rodrigues et al. 2019; Wang et al. 2016; Wang et al. 2019). In parallel, rapid molecular diagnostic protocols for early detection of $P$. citricarpa have been developed in qPCR (Bonants et al. 2003; Van Gent-Pelzer et al. 2007) and loop-mediated isothermal amplification, both with a similar LoD (Tomlinson et al. 2013). PCR assays targeting mating types of $P$. citricarpa and relatives (Amorim et al. 2017; Guarnaccia et al. 2019) have been implemented in parallel with studies focused on distribution, etiology, and epidemiology (Hendricks et al. 2017; Magarey et al. 2015; Martínez-Minaya et al. 2015; Wang and Dewdney 2019; Yonow et al. 2013). We contribute to the cause of understanding CBS with the standardization of a triplex qPCR assay for testing the presence of $P$. citricarpa and its mating types from fruit lesions simultaneously using qPCR, while also standardizing both protocols (ITS and MAT idiomorphs) in the dPCR platform, technology that allows the detection of the P. citricarpa at low levels of pathogen inoculum on asymptomatic tissue. The use of both platforms allowed the rapid and accurate diagnosis of CBS from fruit lesions and asymptomatic leaves, protocols that will complement methods currently in practice for monitoring and certification of citrus in groves and nurseries in Florida and other parts of the world where CBS impacts citrus production.

Future studies should aim toward improving the detection rate of $P$. citricarpa from leaves by employing different manual and automated DNA extraction protocols (e.g., magnetic bead DNA extraction kits that have shown higher extraction efficiency) (Bordelon et al. 2013; He et al. 2017), investigating which amount of inoculum in the tree canopy is necessary to produce disease, standardizing more rigorous field sampling schemes (that take into account anthropogenic movement within and among groves) to assess dispersal abilities of the pathogen, as well as migrating current molecular assays (ITS and MAT) into ddPCR technology with multiplexing capabilities that allow for improvement of sample processing speed. All of these advances will move the field toward the ultimate objective of evaluating the effectiveness of mitigation, management, and eradication procedures against $P$. citricarpa in citrus groves, a challenging task due to the vast acreage of citrus infected with this pathogen in Florida and its uneven distribution within citrus trees and among groves.

\section{ACKNOWLEDGMENTS}

We thank M. Albritton and A. Lawrence for their assistance in geo-pointing and mapping; grove inspectors S. Estrada, A. Gilliland, R. Noah, J. Johnson, and G. Esquivel, who carried out the coordination and collection of fruit and leaves; all of the FDACS-DPI inspectors involved in this study; C. Carroll and N. Denfeld for laboratory technical assistance; and M. Moore and K. Dey for proving meaningful editorial feedback.

\section{LITERATURE CITED}

Amorim, R., Savi, D. C., Ferreira-Maba, L., Aluizio, R., Goulin, E. H., Takita, M. A., Machado, M. A., and Glienke, C. 2017. MAT gene idiomorphs suggest a heterothallic sexual cycle in the citrus pathogen Phyllosticta citricarpa. Eur. J. Plant Pathol. 147:325-337.

Armbruster, D. A., and Pry, T. 2008. Limit of blank, limit of detection and limit of quantitation. Clin. Biochem. Rev. 29:S49-S52.

Bahder, B. W., Helmick, E. E., Mou, D.-F., Harrison, N. A., and Davis, R. 2018. Digital PCR technology for detection of palm-infecting Phytoplasmas belonging to group 16SrIV that occur in Florida. Plant Dis. 102:1008-1014.

Bonants, P. J. M., Carroll, G. C., de Weerdt, M., van Brouwershaven, I. R., and Baayen, R. P. 2003. Development and validation of a fast PCR-based detection method for pathogenic isolates of the citrus black spot fungus, Guignardia citricarpa. Eur. J. Plant Pathol. 109:503-513.

Bordelon, H., Russ, P. K., Wright, D. W., and Haselton, F. R. 2013. A magnetic bead-based method for concentrating DNA from human urine for downstream detection. PLoS One 8:e68369.

Boughalleb-M'Hamdi, N., Fathallah, A., Benfradj, N., Ben Mahmoud, S., Bel Hadj Ali, A., Medhioub, L., Jaouadi, I., Huber, J., Jeandel, C., and Ioos, R. 2020. First report of citrus black spot disease caused by Phyllosticta citricarpa on Citrus limon and C. sinensis in Tunisia. New Dis. Rep. 41:8.

Carstens, E., Linde, C. C., Slabbert, R., Miles, A. K., Donovan, N. J., Li, H., Zhang, K., Dewdney, M. M., Rollins, J. A., Glienke, C., Schutte, G. C., Fourie, P. H., and McLeod, A. 2017. A global perspective on the population structure and reproductive system of Phyllosticta citricarpa. Phytopathology 107:758-768.

de Oliveira Silva, A., Savi, D. C., Raiser, P. H. S., Gonçalves, F. P., Kava, V., Galli-Terasawa, L. V., and Glienke, C. 2017. Epidemiological aspects of Phyllosticta citricarpa colonization and viability in Citrus sinensis. J. Plant Dis. Prot. 124:73-80.

Dewdney, M., Rollins, J., Wang, N.-Y., and Zhang, K. 2016. New knowledge on citrus black spot. Pages 14-17 in: Citrus Industry. https:// crec.ifas.ufl.edu/extension/trade_journals/2016/2016_August_blackspot. pdf

Dreo, T., Pirc, M., Ramšak, Ž., Pavšič, J., Milavec, M., Zel, J., and Gruden, K. 2014. Optimising droplet digital PCR analysis approaches for detection and quantification of bacteria: A case study of fire blight and potato brown rot. Anal. Bioanal. Chem. 406:6513-6528.

Dupas, E., Legendre, B., Olivier, V., Poliakoff, F., Manceau, C., and Cunty, A. 2019. Comparison of real-time PCR and droplet digital PCR for the detection of Xylella fastidiosa in plants. J. Microbiol. Methods 162:86-95.

Faganello, F. D. E. S., Carrer Filho, R., Dias, V. D., Morello, R. M. S. C., and Cunha, M. G. D. A. 2017. Molecular diagnosis of Guignardia citricarpa in asymptomatic sweet orange tissue. Rev. Bras. Frutic. 39:1-7.

Glienke, C., Pereira, O. L., Stringari, D., Fabris, J., Kava-Cordeiro, V., GalliTerasawa, L., Cunnington, J., Shivas, R. G., Groenewald, J. Z., and Crous, P. W. 2011. Endophytic and pathogenic Phyllosticta species, with reference to those associated with citrus black spot. Persoonia 26:47-56.

Gottwald, T. R., Hughes, G., Graham, J. H., Sun, X., and Riley, T. 2001. The citrus canker epidemic in Florida: The scientific basis of regulatory eradication policy for an invasive species. Phytopathology 91:30-34.

Guarnaccia, V., Gehrmann, T., Silva-Junior, G. J., Fourie, P. H., Haridas, S., Vu, D., Spatafora, J., Martin, F. M., Robert, V., Grigoriev, I. V., Groenewald, J. Z., and Crous, P. W. 2019. Phyllosticta citricarpa and sister species of global importance to Citrus. Mol. Plant Pathol. 20:1619-1635. 
Halbert, S. E., and Manjunath, K. L. 2004. Asian citrus psyllids (Sternorrhyncha: Psyllidae) and greening disease of citrus: A literature review and assessment of risk in Florida. Fla. Entomol. 87:330-353.

He, H., Li, R., Chen, Y., Pan, P., Tong, W., Dong, X., Chen, Y., and Yu, D. 2017. Integrated DNA and RNA extraction using magnetic beads from viral pathogens causing acute respiratory infections. Sci. Rep. 7:45199.

Hendricks, K. E., Christman, M., and Roberts, P. D. 2017. Spatial and temporal patterns of commercial citrus trees affected by Phyllosticta citricarpa in Florida. Sci. Rep. 7:1641.

Hendricks, K. E., Christman, M. C., and Roberts, P. D. 2020. The effect of weather and location of fruit within the tree on the incidence and severity of citrus black spot on fruit. Sci. Rep. 10:1389.

Higgins, B. B. 1929. Morphology and life history of some ascomycetes with special reference to the presence and function of spermatia II. Am. J. Bot. 16:287-296.

Hu, J., Johnson, E. G., Wang, N.-Y., Davoglio, T., and Dewdney, M. M. 2014. qPCR quantification of pathogenic Guignardia citricarpa and nonpathogenic G. mangiferae in citrus. Plant Dis. 98:112-120.

Hudson, M. E. 2019. Florida Citrus Statistics 2017-2018. Florida Department of Agriculture and Consumer Services, Tallahassee, FL. https://www.nass.usda.gov/Statistics_by_State/Florida/Publications/ Citrus/Citrus_Statistics/2017-18/fcs1718.pdf.

Integrated DNA Technologies. 2018. Integrated DNA Technologies.

Karlin-Neumann, G., and Bizouarn, F., eds. 2018. Digital PCR: Methods and Protocols. Methods in Molecular Biology, Vol. 1768. Springer, New York, NY, U.S.A.

Laig, M., Fekete, C., and Majumdar, N. 2020. Digital PCR and the QuantStudio $^{\text {TM }}$ 3D Digital PCR System. Pages 209-231 in: Quantitative Real-Time PCR. R. Biassoni and A. Raso, eds. Methods in Molecular Biology, Vol. 2065. Springer, New York, NY, U.S.A.

Magarey, R. D., Hong, S. C., Fourie, P. H., Christie, D. N., Miles, A. K., Schutte, G. C., and Gottwald, T. R. 2015. Prediction of Phyllosticta citricarpa using an hourly infection model and validation with prevalence data from South Africa and Australia. Crop Prot. 75:104-114.

Martínez-Minaya, J., Conesa, D., López-Quílez, A., and Vicent, A. 2015. Climatic distribution of citrus black spot caused by Phyllosticta citricarpa. A historical analysis of disease spread in South Africa. Eur. J. Plant Pathol. 143:69-83.

Matheson, C. D., Marion, T. E., Hayter, S., Esau, N., Fratpietro, R., and Vernon, K. K. 2009. Technical note: Removal of metal ion inhibition encountered during DNA extraction and amplification of copperpreserved archaeological bone using size exclusion chromatography. Am. J. Phys. Anthropol. 140:384-391.

McVay, J., Sun, X., Jones, D., Urbina, H., Aldeek, F., Cook, J. M., Jeyaprakash, A., Hodges, G., and Smith, T. 2019. Limited persistence of residues and metabolites in fruit and juice following penicillin trunk infusion in citrus affected by Huanglongbing. Crop Prot. 125:104753.

Meyer, L., Jacobs, R., Kotzé, J. M., Truter, M., and Korsten, L. 2012. Detection and molecular identification protocols for Phyllosticta citricarpa from citrus matter. S. Afr. J. Sci. 108:53-59.

Milosevic, D., Mills, J. R., Campion, M. B., Vidal-Folch, N., Voss, J. S., Halling, K. C., Highsmith, W. E., Liu, M. C., Kipp, B. R., and Grebe, S. K. G. 2018. Applying standard clinical chemistry assay validation to droplet digital PCR quantitative liquid biopsy testing. Clin. Chem. 64:1732-1742.

Oksanen, J., Blanchet, F. G., Friendly, M., Kindt, R., Legendre, P., McGlinn, D., Minchin, P. R., O'Hara, R. B., Simpson, G. L., Solymos, P., Stevens, M. H. H., Szoecs, E., and Wagner, H. 2007. vegan: Community ecology package. https://cran.r-project.org/web/packages/ vegan/index.html

Perryman, S. A. M., Clark, S. J., and West, J. S. 2014. Splash dispersal of Phyllosticta citricarpa conidia from infected citrus fruit. Sci. Rep. 4:6568.

Ripley, B. D. 2001. The R project in statistical computing. MSOR Connections. The newsletter of the LTSN Maths. https://www.r-project.org/

Rodrigues, C. M., Takita, M. A., Silva, N. V., Ribeiro-Alves, M., and Machado, M. A. 2019. Comparative genome analysis of Phyllosticta citricarpa and Phyllosticta capitalensis, two fungi species that share the same host. BMC Genomics 20:554.
Schirmacher, A. M., Tomlinson, J. A., Barnes, A. V., and Barton, V. C. 2019. Species-specific real-time PCR for diagnosis of Phyllosticta citricarpa on Citrus species. Bull. OEPP/EPPO Bull. 49:306-313.

Schubert, T., Sutton, B., and Jeyaprakash, A. 2010. Citrus black spot (Guignardia citricarpa) discovered in Florida DACS-P-01723. https:// www.fdacs.gov/content/download/9770/file/guignardia-citricarpa.pdf

Selvaraj, V., Maheshwari, Y., Hajeri, S., Chen, J., McCollum, T. G., and Yokomi, R. 2018. Development of a duplex droplet digital PCR assay for absolute quantitative detection of "Candidatus Liberibacter asiaticus.". PLoS One 13:e0197184.

Tomlinson, J. A., Ostoja-Starzewska, S., Webb, K., Cole, J., Barnes, A., Dickinson, M., and Boonham, N. 2013. A loop-mediated isothermal amplification-based method for confirmation of Guignardia citricarpa in citrus black spot lesions. Eur. J. Plant Pathol. 136:217-224.

Tran, N. T., Miles, A. K., Dietzgen, R. G., Dewdney, M. M., Zhang, K., Rollins, J. A., and Drenth, A. 2017. Sexual reproduction in the citrus black spot pathogen, Phyllosticta citricarpa. Phytopathology 107:732-739.

Tran, N. T., Miles, A. K., Dietzgen, R. G., Shuey, T. A., Mudge, S. R., Papacek, D., Chandra, K. A., and Drenth, A. 2020. Inoculum dynamics and infection of citrus fruit by Phyllosticta citricarpa. Phytopathology 110:1680-1692.

Urbina, H., and Aime, M. C. 2018. A closer look at Sporidiobolales: Ubiquitous microbial community members of plants and food biospheres. Mycologia 110:79-92.

USDA APHIS. 2020. Citrus Black Spot. https://www.aphis.usda.gov/ aphis/ourfocus/planthealth/plant-pest-and-disease-programs/pests-anddiseases/citrus/citrus-black-spot/citrus-black-spot

van der Aa, H. A. 1973. Studies in Phyllosticta I. Stud. Mycol. 5:1-110.

Van Gent-Pelzer, M. P. E., Van Brouwershaven, I. R., Kox, L. F. F., and Bonants, P. J. M. 2007. A aqMan PCR method for routine diagnosis of the quarantine fungus Guignardia citricarpa on citrus fruit. J. Phytopathol. 155:357-363.

Wang, M., Liu, B., Ruan, R., Zeng, Y., Luo, J., andLi, H. 2019. Genomic sequencing of Phyllosticta citriasiana provides insight into its conservation and diversification with closely related Phyllosticta species associated with citrus. BioRxiv.

Wang, N.-Y., and Dewdney, M. M. 2019. The effects of nutrition and environmental factors on conidial germination and appressorium formation of Phyllosticta citricarpa, the causal agent of citrus black spot. Phytopathology 109:650-658.

Wang, N.-Y., Zhang, K., Huguet-Tapia, J. C., Rollins, J. A., and Dewdney, M. M. 2016. Mating type and simple sequence repeat markers indicate a clonal population of Phyllosticta citricarpa in Florida. Phytopathology 106:1300-1310.

White, T. J., Bruns, T., Lee, S., and Taylor, J. 1990. Amplification and direct sequencing of fungal ribosomal RNA genes for phylogenetics. Pages 315-322 in: PCR Protocols: A Guide to Methods and Applications. M. A. Innis, D. H. Gelfand, J. J. Sninsky, and T. J. White, eds. Academic Press, San Diego, CA, U.S.A.

Wickham, H. 2016. ggplot2: Elegant Graphics for Data Analysis. Springer, New York, NY.

Wikee, S., Udayanga, D., Crous, P. W., Chukeatirote, E., McKenzie, E. H. C., Bahkali, A. H., Dai, D., and Hyde, K. D. 2011. Phyllosticta-An overview of current status of species recognition. Fungal Divers. 51:43-61.

Ye, J., Coulouris, G., Zaretskaya, I., Cutcutache, I., Rozen, S., and Madden, T. L. 2012. Primer-BLAST: A tool to design target-specific primers for polymerase chain reaction. BMC Bioinf. 13:134.

Yonow, T., Hattingh, V., and de Villiers, M. 2013. CLIMEX modelling of the potential global distribution of the citrus black spot disease caused by Guignardia citricarpa and the risk posed to Europe. Crop Prot. 44:18-28.

Zhang, K. 2017. The population structure of Phyllosticta citricarpa and seasonal dynamics of Phyllosticta spp. in Floridian citrus groves. Dissertation, Doctor of Philosophy, The University of Florida.

Zhong, X., Liu, X.-L., Lou, B.-H., Zhou, C.-Y., and Wang, X.-F. 2018 Development of a sensitive and reliable droplet digital PCR assay for the detection of "Candidatus Liberibacter asiaticus.". J. Integr. Agric. $17: 483-487$ 